\title{
Oxidative stress parameters in juvenile Brazilian flounder Paralichthys orbignyanus (Valenciennes, 1839) (Pleuronectiformes: Paralichthyidae) exposed to cold and heat shocks
}

\author{
Luciano de O. Garcia ${ }^{1}$, Marcelo H. Okamoto², Ana Paula K. Riffel ${ }^{3}$, Etiane M. Saccol ${ }^{3}$, \\ Maria A. Pavanato ${ }^{3}$ and Luís André N. Sampaio ${ }^{2}$
}

\begin{abstract}
The aim of this study was to determine oxidative stress parameters in the liver and gill of Brazilian flounder juveniles (307.0 $\pm 16.0 \mathrm{~g}$ and $30.0 \pm 4.0 \mathrm{~cm}$ ) submitted to different water temperature $\left(17.1,23.0\right.$ and $\left.28.8^{\circ} \mathrm{C}\right)$ for $72 \mathrm{~h}$ and maintained at salinity $25 \%$. After the acclimation of 7 days, in $23^{\circ} \mathrm{C}$, fish were transferred to $200 \mathrm{~L}$ tanks containing seawater (salinity $25 \%$ ) at $28.8^{\circ} \mathrm{C}$ (heat shock), $17.1^{\circ} \mathrm{C}$ (cold shock) or $23.0^{\circ} \mathrm{C}$ (control), five replicates (five fish tank ${ }^{-1}$ ). The sampled collection occurred in 0 (pre-challenge), 3, 24, 48 and $72 \mathrm{~h}$ after temperature shock. Flounder exposed to $17.1^{\circ} \mathrm{C}$ and $28.8^{\circ} \mathrm{C}$ showed significantly higher TBARS levels and GST activity in the liver post-exposition (PE) in relation to the control $\left(23^{\circ} \mathrm{C}\right)$. CAT activity in liver present a significantly increase at $17.1^{\circ} \mathrm{C}$, in first $48 \mathrm{~h}$, and subsequently decrease in $72 \mathrm{~h} \mathrm{PE}$ in relation to $28.8^{\circ} \mathrm{C}$. The gills of flounder showed significantly higher TBARS levels, GST and CAT activity when submitted at 17.1 and $28.8^{\circ} \mathrm{C}$ in relation to $23.0^{\circ} \mathrm{C}$. There were observed changes in lipid peroxidation levels (LPO), CAT and GST activities in the liver and gill of Brazilian flounder in response to reactive oxygen species (ROS) produced by thermal shocks.

O objetivo deste estudo foi determinar os parâmetros de estresse oxidativo no fígado e brânquias de juvenis de linguado $(307,0 \pm 16,0 \mathrm{~g}$ e $30,0 \pm 4,0 \mathrm{~cm})$ submetidos a diferentes temperaturas da água $\left(17,1,23,0\right.$ e $\left.28,8^{\circ} \mathrm{C}\right)$ por $72 \mathrm{~h}$ e mantidos na salinidade de $25 \%$. Após uma aclimatação de sete dias, em $23^{\circ} \mathrm{C}$, os peixes foram transferidos para tanques de 200 $\mathrm{L}$ contendo água do mar (salinidade $25 \%$ ) em $28,8^{\circ} \mathrm{C}$ (choque quente), $17,1^{\circ} \mathrm{C}$ (choque frio) ou $23,0^{\circ} \mathrm{C}$ (controle), cinco repetições (cinco peixes/tanque). A coleta de amostras ocorreu em 0 (pré-exposição), 3, 24, 48 e 72 h após o choque térmico. O linguado exposto a $17,1^{\circ} \mathrm{C}$ e $28,8^{\circ} \mathrm{C}$ apresentaram um significante aumento dos níveis de TBARS e atividade da GST no fígado pós-exposição (PE) em relação ao controle $\left(23^{\circ} \mathrm{C}\right)$. A atividade da CAT no fígado apresentou um aumento significativo em $17,1^{\circ} \mathrm{C}$, nas primeiras $48 \mathrm{~h}$, e subsequente diminuição em $72 \mathrm{~h} \mathrm{PE}$ em relação a $28,8^{\circ} \mathrm{C}$. As brânquias do linguado apresentaram significante aumento dos níveis de TBARS e atividade da GST e CAT quando submetidos a $17,1^{\circ} \mathrm{C}$ e $28,8^{\circ} \mathrm{C}$ em relação a $23,0^{\circ} \mathrm{C}$. Foram observadas alterações nos níveis de peroxidação lipídica (LPO) e atividade de GST e CAT no fígado e brânquias de linguado em resposta as espécies reativas de oxigênio (ROS) produzidas pelo choque térmico.
\end{abstract}

Keywords: Catalase, GST, Lipid peroxidation, TBARS, Thermal shocks.

\section{Introduction}

Aquatic animals are constantly exposed to temperature variations in the natural environmental and culture farms in the State of Rio Grande do Sul, south of Brazil, due to seasonal thermal amplitudes. Temperature variations occur very frequently in estuarine environmental, where this species inhabits (Laguna dos Patos estuary, southern Brazil). In this habitat, temperature can vary from 10 to $30^{\circ} \mathrm{C}$ due to seasonal fluctuations or influence of climate change (Garcia et al., 2003). These climate alterations in recent years tend to contribute in changes which may result in injury for animal integrity, in addition the different species that inhabit the estuary can present alterations in cellular biomarkers. This includes gene and protein changes, metabolism, energy, immune, endocrine, neural and even behavioral changes that will first try to overcome that situation and then compensate for the imbalances produced by either the stressor or the consequences generated by their responses (Tort, 2011).

\footnotetext{
${ }^{1}$ Instituto de Oceanografia, Laboratório de Qualidade da Água, Universidade Federal do Rio Grande (FURG), 96210-030 Rio Grande, RS, Brazil.garcia_log@hotmail.com (corresponding author)

${ }_{2}^{2}$ Instituto de Oceanografia, Laboratório de Piscicultura Estuarina e Marinha, Universidade Federal do Rio Grande (FURG), 96210-030 Rio Grande, RS, Brazil. (MHO) mar_okamoto@yahoo.com.br, (LANS) sampaio@mikrus.com.br ${ }^{3}$ Departamento de Fisiologia e Farmacologia, Universidade Federal de Santa Maria, 97105-900 Santa Maria, RS, Brazil. (APKR) anapkriffel@hotmail.com, (EMS) etianesaccol@hotmail.com, (MAP) amaliapavanato@yahoo.com.br
} 
The flounder Paralichthys orbignyanus (Valenciennes, 1839) occurs in estuarine and coastal waters from Rio de Janeiro (Brazil) to Mar del Plata (Argentina) (Figueiredo \& Menezes, 2000). This species is an important item for local fisheries in the south Brazil, and presents all characteristics essential for aquaculture (Sampaio et al., 2007). It is known for tolerance to a wide range of temperature (Wasielesky et al., 1998) and salinity (Sampaio \& Bianchini, 2002), nitrogenous compounds (Bianchini et al., 1996), and acid stress (Wasielesky et al., 1997).

In another species of flounder Platichthys stellatus, higher temperatures cause an increase in oxygen consumption. As a consequence, there is an increase of ventilation volume, cardiac output, and ventilationreperfusion ratio (Watters \& Smith, 1973). However, a sharp temperature increase or decrease can cause heat shock, thus stimulating numerous changes in different fish species. Changing temperature can lead to metabolic activation, which combined with an increase in oxygen consumption, initiates the oxidative stress process (Storey, 1996; Hermes-Lima, 2004). Cells subjected to heat shock can respond to it by an increase in the antioxidant defenses, particularly the antioxidant and associated enzymes (Hermes-Lima, 2004).

Oxidative stress is defined as an unbalanced state between pro-oxidants and antioxidants, resulting in elevated production of reactive oxygen species (ROS) and free radicals, agents potentially deleterious to the organism (Halliwell, 1992; Matés et al., 1999; Halliwell \& Gutteridge, 1999). This process can be induced by a large variety of conditions, including nutritional imbalance, exposure to chemical and physical environmental agents, strenuous physical activities, injury, and hereditary disorders (Chow, 1991). Imbalance between pro-oxidant and antioxidant levels can induce damage to DNA and RNA, inducing mutations. In addition, it causes oxidation of thiol groups (-SH) in enzymes and other proteins, therefore causing lipid peroxidation, which may induce changes in membrane permeability, loss of secretory function, and even cell death. Tissue damage and the subsequent release of pro oxidants results in a series of events at the intracellular level that leads to oxidative stress (Halliwell, 1992; Halliwell \& Gutteridge, 1999), which can be detected through measurement of oxidative stress parameters.

This study is necessary due to changes that occur in the estuarine environment, with alterations in water temperature in a short period of time. These alterations may decrease the levels of dissolved oxygen in the water and consequently an unbalance in the ratio pro/antioxidants, featuring a state of oxidative stress. Therefore, the aim of this study was to determine oxidative stress parameters (CAT and GST) and lipid peroxidation in the liver and gill of juvenile Brazilian flounder exposed to heat and cold shocks.

\section{Material and Methods}

Experimental fish and acclimation. Sixty-five Brazilian flounder $(307.0 \pm 16.0 \mathrm{~g}$ and $30.0 \pm 4.0 \mathrm{~cm})$ produced and reared at the Aquaculture Marine Station of the Universidade Federal do Rio Grande (FURG) in south Brazil, were acclimated during 16 days in three tanks $(500 \mathrm{~L})$ equipped with recirculating aquaculture systems. The fish were fed twice daily with commercial diet (Supra Salmonídeos, $46 \%$ crude protein) until apparent satiation. Water temperature and salinity were maintained at $23.0 \pm$ $0.4^{\circ} \mathrm{C}$ and $25 \%$, respectively.

Temperature exposure and tanks management. After the acclimation period under the control temperature $\left(23^{\circ} \mathrm{C}\right)$, fish were randomly transferred to $200 \mathrm{~L}$ tanks containing seawater at $29^{\circ} \mathrm{C}$ (heat shock), $17^{\circ} \mathrm{C}$ (cold shock) or $23^{\circ} \mathrm{C}$ (control). Four tanks were used for each temperature and five fish were placed in each tank. Others five fish were placed in one tank, in the same acclimation conditions, which formed a new group $(0 \mathrm{~h}$ or prechallenge).

The maintenance of the lower experimental temperature $\left(17^{\circ} \mathrm{C}\right)$ was performed adding PET bottles with ice inside the tanks, when necessary. The other experimental temperatures $\left(23\right.$ and $\left.29^{\circ} \mathrm{C}\right)$ were maintained by submerged heaters as described above. Once a day, $50 \%$ of the water volume of the tanks corresponding to 48 and $72 \mathrm{~h}$ was renewed with water storage in reservoirs kept under the same conditions of temperature and salinity of the experimental tanks. During the experimental period, temperatures remained $17.1 \pm 0.1,23.0 \pm 0.2$ and $28.8 \pm$ $0.1^{\circ} \mathrm{C}$ and salinity remained $25 \%$ for all treatments. Fish were not fed for about $24 \mathrm{~h}$ prior to challenge neither during the temperature exposure. Alkalinity $(172.4 \pm 5.9$ mg $\mathrm{CaCO}_{3} \mathrm{~L}^{-1}$ ) (Baumgarten et al., 1996), total ammonia $\left(1.38 \pm 0.03 \mathrm{mg} \mathrm{L}^{-1}\right)($ Unesco, 1983), nitrite $(0.05 \pm 0.02)$ (Bendschneider \& Robinson, 1952), $\mathrm{pH}(8.2 \pm 0.4)$ and dissolved oxygen $\left(5.9 \pm 0.8 \mathrm{mg} \mathrm{L}^{-1}\right)$ (multi-parameter YSI 556) remained in suitable conditions to the specie during all experimental period.

Tissues collection. Each challenge protocol (including the control treatment) was applied to five replicates (five fish $\tan ^{-1}$ ) where each tank accounted a sampling point: 3, 24, 48 and $72 \mathrm{~h}$ after temperature shock. Group prechallenge ( $\mathrm{N}=$ five fish) was sampled before the exposure to the temperature shock.

At each sampling point, fish were netted in a single pass with a large net to minimize sampling effort and stress associated with repeat netting. Fish were immediately sedated with benzocaine $(50 \mathrm{ppm})$ (Henrifarma Produtos Químicos e Farmacêuticos LTDA, Brazil) and euthanized by single cranial pithing following tissues collection (liver and gills). After, the tissues were stored in a $-80^{\circ} \mathrm{C}$ freezer for subsequent analysis. 
Enzimatic assay. Liver and gill tissues were homogenized in $1.15 \% \quad\left(\mathrm{w} \quad \mathrm{V}^{-1}\right) \quad \mathrm{KCl}$ solution containing $1 \mathrm{mM}$ Phenylmethylsulphonyl-Fluoride (PMSF). Homogenates were centrifuged at $1000 \mathrm{~g}$ for $10 \mathrm{~min}$ to eliminate nuclei and cell debris and the supernatant fraction obtained was frozen at $-80^{\circ} \mathrm{C}$ for further measurements (Azambuja et al., 2011). Supernatants were used for analysis of thiobarbituric acid reactive substances (TBARS), catalase (CAT 1.11.1.6) and glutathione transferase (GST EC 2.5.1.18). Lipid peroxidation was measured by TBARS using methods described by Buege \& Aust (1978). Briefly, absorbance measurements at $535 \mathrm{~nm}$ were used to measure the reaction between thiobarbituric acid and lipoperoxidation (LPO) products, resulting in the formation of a chromogen (Schiff's base). Results were reported as nmol $\mathrm{mg}^{-1}$ protein. The protein content of homogenates was measured using methods described in Lowry et al. (1951), using bovine serum albumin (BAS) as the standard. CAT activity was determined by according to methods described by Boveris \& Chance (1973), in which $\mathrm{H}_{2} \mathrm{O}_{2}$ loss is followed spectrophotometrically at $240 \mathrm{~nm}$. Results were reported as pmol mg/protein. GST activity was determined spectrophotometrically at $340 \mathrm{~nm}$ using the method described in Habig et al. (1974). Activity was calculated by monitoring changes in absorbance at 340 $\mathrm{nm}$ using an extinction coefficient of $9.6 \mathrm{mmol} \mathrm{cm}^{-1}$. One unit of GST activity was defined as the amount of enzyme catalyzing the conjugation of $1 \mu \mathrm{mol}$ of CDNB (1-chloro-2,4dinitrobenzene) with $\mathrm{GSH}$ per min at $25^{\circ} \mathrm{C}$.

Statistical analysis. Data are reported as means \pm SEM $(\mathrm{N}=5)$. Homogeneity of variances among groups was tested with the Levene test. Data for TBARS, CAT and GST had homogeneous variances and comparisons between different treatments were made using two-way analysis of variance and the Dunnet test. Analysis was performed using Statistica 7.0 software and minimum significance levels were set at 0.05 .

\section{Results}

Oxidative stress parameters from control fish did not show any significant differences at the time of collection and were therefore pooled and considered as $0 \mathrm{~h}$ or pre-challenge. Flounder exposed to $17.1^{\circ} \mathrm{C}$ showed higher TBARS levels in the liver $(81.7 \%)$ compared to those fish kept at $28.8^{\circ} \mathrm{C}$ in the period of $3 \mathrm{~h}$ post-exposition (PE). The inverse occurs in the period of $24 \mathrm{~h}$ PE when the TBARS levels in the liver were higher (148.5\%) in $28.8^{\circ} \mathrm{C}$ in relation to $17.1^{\circ} \mathrm{C}$. TBARS levels in $48 \mathrm{~h}$ PE showed higher activity in fishes exposed to 17.1 $(97.6 \%)$ and $28.8^{\circ} \mathrm{C}(83.3 \%)$ compared to $23.0^{\circ} \mathrm{C}$ (Fig. 1a).
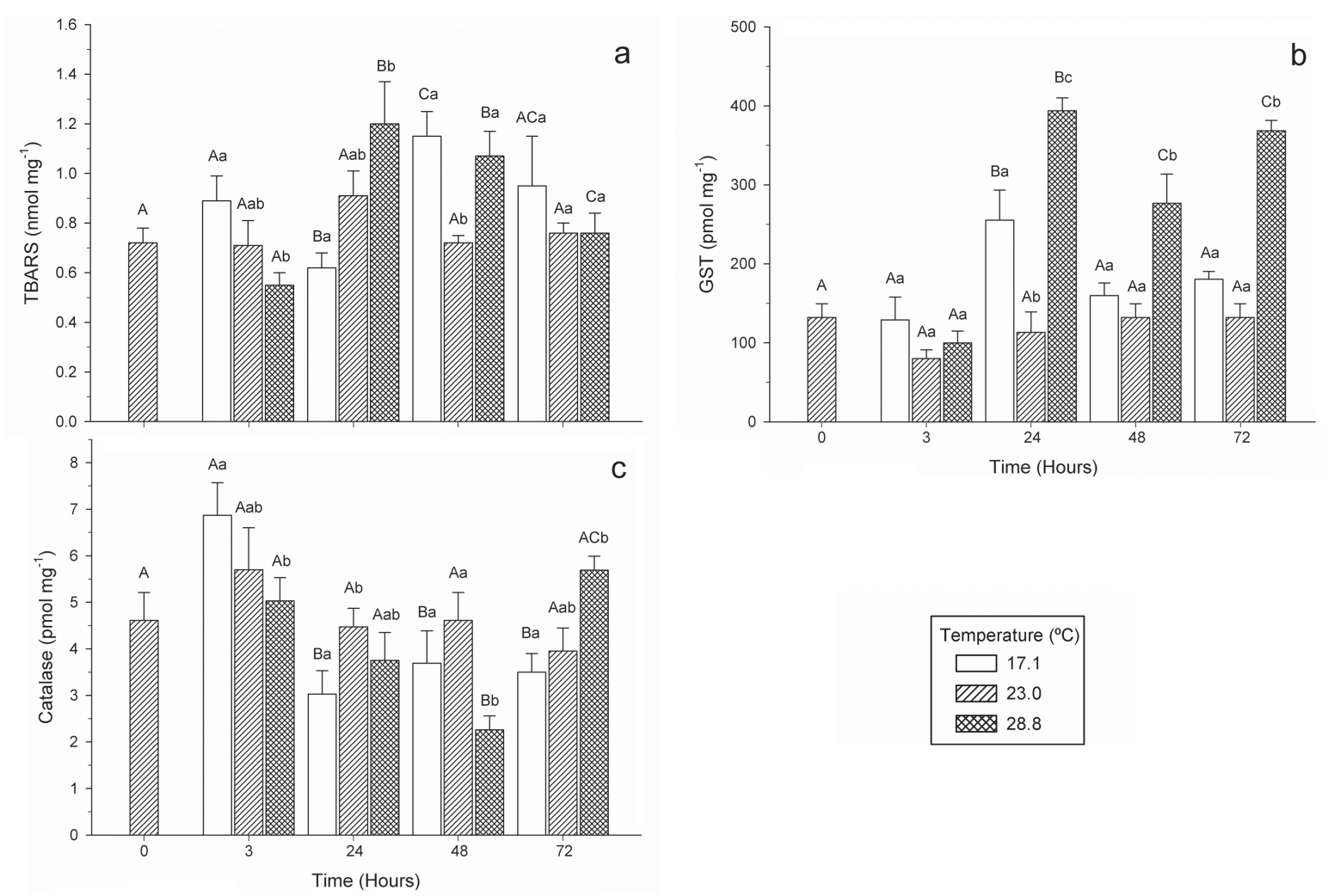

Fig. 1. (TBARS), (GST) and (CAT) activity in the liver of Paralichthys orbignyanus juveniles exposed to different temperatures $\left(17.1,23.0\right.$ and $\left.28.8^{\circ} \mathrm{C}\right)$ as a function of time exposition $(72 \mathrm{~h})$. Values are expressed as means $\pm \mathrm{SEM}, \mathrm{N}=5$. ${ }^{a}$ Lower case letters indicate significantly different at the different temperatures and same time $(P<0.05)$, determined by two-way ANOVA and by Dunnet test. ${ }^{A}$ Capital letters indicate significantly different at the same temperatures and different times $(P<0.05)$, determined by two-way ANOVA and by Dunnet test. 
TBARS activity in liver among all times in the same temperature of $17.1^{\circ} \mathrm{C}$ showed an increase, except in $24 \mathrm{~h}$ PE where there is a decrease $(33 \%)$, in relation to the prechallenge. This activity also demonstrates an increase in the periods of 24 and $48 \mathrm{~h} \mathrm{PE} \mathrm{(124.7} \mathrm{and} 92.7 \%$ respectively) in temperature of $28.8^{\circ} \mathrm{C}$ in relation to the pre-challenge and the same treatment and other periods.

In liver, GST activity was higher at $28.8^{\circ} \mathrm{C}$ in relation to 17.1 and $23.0^{\circ} \mathrm{C}$ in all experimental period $\mathrm{PE}$, except in $3 \mathrm{~h}$. GST activity in temperature of $17.1^{\circ} \mathrm{C}$ present an increase in $24 \mathrm{~h} \mathrm{PE}$ in relation to $23.0^{\circ} \mathrm{C}$. In $24 \mathrm{~h} \mathrm{PE}$, GST activity was higher in treatment of $17.1^{\circ} \mathrm{C}$ in relation to the control and same treatment in other times. This increase is also observed to $28.8^{\circ} \mathrm{C}$ in relation to the control and same temperature after $24 \mathrm{~h}$ PE (Fig. 1b).

Flounder exposed to $17.1^{\circ} \mathrm{C}$ present an increase CAT levels in liver in relation to $28.8^{\circ} \mathrm{C}$ at 3 and $48 \mathrm{~h} \mathrm{PE}(62.5$ and $80.7 \%$ respectively), and in the period of 24 and $72 \mathrm{~h}$ $\mathrm{PE}$ showed a decrease in this levels in relation to treatment of $23.0(42.1 \%)$ and $28.8^{\circ} \mathrm{C}(57.3 \%)$, respectively. CAT activity showed a decrease in treatment of $17.1^{\circ} \mathrm{C}$ after $24 \mathrm{~h}$ in relation to the pre-challenge $(66.0 \%)$ and same treatment in $3 \mathrm{~h}(221.4 \%)$. Flounder exposed to $28.8^{\circ} \mathrm{C}$ present a decrease in $48 \mathrm{~h} \mathrm{PE}$ in relation to same treatments in the different times (Fig. 1c).

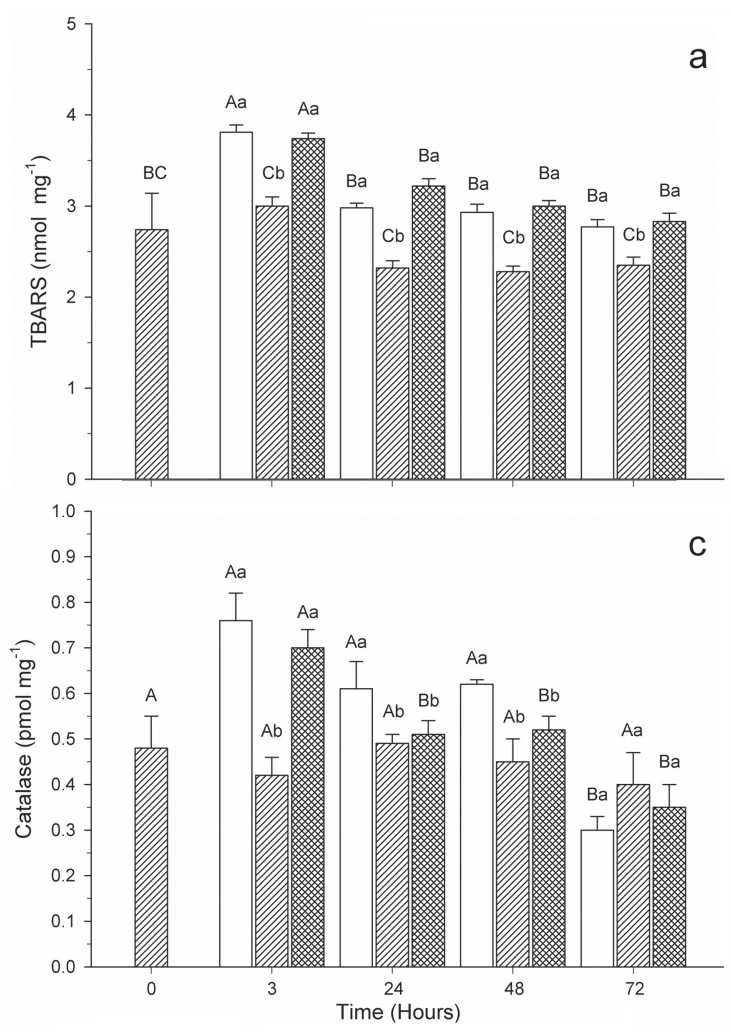

The gills of flounder showed higher TBARS activity at all experimental times when submitted at $17.1(70.4,54.6$, 57.9 and $42.3 \%)$ and $28.8^{\circ} \mathrm{C}(69.1,77.5,61.3$ and $43.2 \%)$ in relation to $23.0^{\circ} \mathrm{C}$. There was also a higher in TBARS activity in temperature of 17.1 and $28.8^{\circ} \mathrm{C}$, in the period of $3 \mathrm{~h} \mathrm{PE}$, when compared to the pre-challenge and same temperature over the time (Fig. 2a).

GST and CAT activity in gills of flounder fish showed a higher in the treatment with 17.1 and $28.8^{\circ} \mathrm{C}$ in relation to $23.0^{\circ} \mathrm{C}(3 \mathrm{~h})$ respectively (Figs. $\left.2 \mathrm{~b}-\mathrm{c}\right)$. There was also an increase in the enzymatic activity of GST in $17.1(134.9 \%)$ and $23.0^{\circ} \mathrm{C}(122.8 \%)$ when compared to $28.8^{\circ} \mathrm{C}$ in $24 \mathrm{~h}$ (Fig. 2b). Inverse occurs in $23.0(34.3 \%)$ and $28.8^{\circ} \mathrm{C}(47.6 \%)$ in relation to $17.1^{\circ} \mathrm{C}$ in $24 \mathrm{~h}$ when the CAT activity decrease (Fig. 2c). GST and CAT activity in $48 \mathrm{~h}$ presented a higher in $17.1^{\circ} \mathrm{C}$ in comparison to 23.0 and $28.8^{\circ} \mathrm{C}$ (Figs. 2b-c) and at the end $(72 \mathrm{~h})$ occurred an increase in GST activity in $17.1(178.9 \%)$ and $23.0^{\circ} \mathrm{C}(139.4 \%)$ in relation to $28.8^{\circ} \mathrm{C}$ (Fig. 2b). In relation to the same temperature and different times, after $3 \mathrm{~h}$ GST and CAT activity showed a higher in the temperature of 17.1 and $28.8^{\circ} \mathrm{C}$ in comparison to the pre-challenge and the same treatment in $72 \mathrm{~h}$ (Figs. 2b-c). There is also an increase CAT activity in $28.8^{\circ} \mathrm{C}$ in the same treatment in the periods of $24(78.6 \%), 48(71.2 \%)$ and $72 \mathrm{~h}(54.8 \%)$ (Fig. $2 \mathrm{c}$ ), in relation to $3 \mathrm{~h}$.
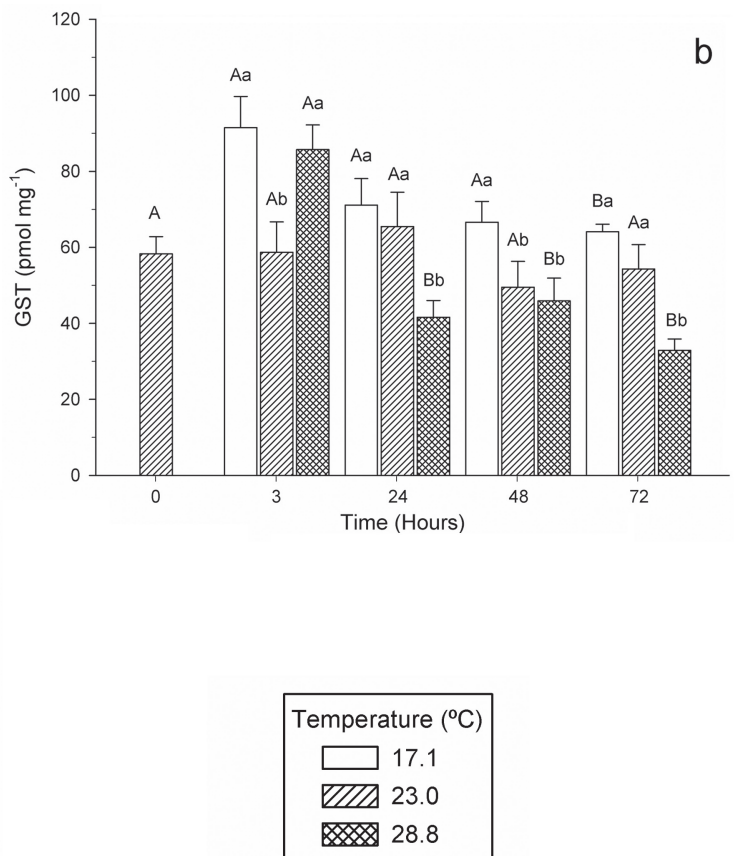

Fig. 2. (TBARS), (GST) and (CAT) activity in the gills of Paralichthys orbignyanus juveniles exposed to different temperatures $\left(17.1,23.0\right.$ and $\left.28.8^{\circ} \mathrm{C}\right)$ as a function of time exposition $(72 \mathrm{~h})$. Values are expressed as means $\pm \mathrm{SEM}, \mathrm{N}=5$. ${ }^{a}$ Lower case letters indicate significantly different at the different temperatures and same time $(P<0.05)$, determined by two-way ANOVA and by Dunnet test. ${ }^{A}$ Capital letters indicate significantly different at the same temperatures and different times $(P<0.05)$, determined by two-way ANOVA and by Dunnet test. 


\section{Discussion}

Temperature is an important factor for aquatic animals which are dependents on this variable for their survival and development (Bhat \& Desai, 1998), moreover great variations in this parameter cause alterations in the stress oxidative parameters (Malek et al., 2004; Bagnyukova et al., 2006, 2007a, 2007b). In our work, changes in LPO levels, CAT and GST activities in the liver and gill of flounder fish submitted to different temperatures were detected.

Activity of LPO parameters in Brazilian flounder exposed to water temperature of $17.1^{\circ} \mathrm{C}$ presented slight increase in the liver at 3 and $48 \mathrm{~h}$ when compared to 28.8 and $23.0^{\circ} \mathrm{C}$ (control), respectively. These levels also are demonstrated to $28.8^{\circ} \mathrm{C}$ in the period of 24 and $48 \mathrm{~h}$ in relation to the 17.1 and $23.0^{\circ} \mathrm{C}$, respectively. This increase probably occurs due to heat shock in the first hours $\mathrm{PE}$ and to the end the levels decreased to near control values, demonstrating perhaps that an adaptation occurs over exposure time $(72 \mathrm{~h})$. In adult zebra fish (Danio rerio) and sea bass (Dicentrarchus labrax), submitted to temperature of 28 to $18^{\circ} \mathrm{C}$ and 28 or $18^{\circ} \mathrm{C}$, respectively, also occur alterations in LPO of skeletal muscle causing oxidative stress (Malek et al., 2004; Vinagre et al., 2012). LPO levels also increase after heat shock (transfer of 19 to $32^{\circ} \mathrm{C}$ ) exposure during $1 \mathrm{~h}$ in liver, muscle and brain of Perccottus glenii, but reverse to the control levels in lower temperatures $\left(19^{\circ} \mathrm{C}\right)$ (Bagnyukova et al., 2007a). Similar results were obtained with goldfish submitted to heat shocks (liver, kidney and brain), and in other work acclimated in $3^{\circ} \mathrm{C}$ and exposed to $23^{\circ} \mathrm{C}$ (liver) which LPO levels increase (Bagnyukova et al., 2006, 2007b).

Brazilian flounder exposed to 17.1 and $28.8^{\circ} \mathrm{C}$ showed an increase in CAT activity in the gill and liver, respectively, in relation to exposed to $23.0^{\circ} \mathrm{C}$ (control), probably due to higher $\mathrm{H}_{2} \mathrm{O}_{2}$ production in this organ with result of cold and heat stress. This increase in the activity suggests that a scavenging ROS occurs by enzyme in cells and tissues helping to clear the peroxides accumulated under stress conditions. These alterations are also observed in white muscle of sea bass juveniles (D. labrax) which had an increase in the CAT levels when exposed to 18 and $28^{\circ} \mathrm{C}$, outside thermal optimum range (Vinagre et al., 2012).

In other study, goldfish submitted to acute transfer 3 to $23^{\circ} \mathrm{C}$ showed CAT levels slightly increased in the brain at period of 12 to $24 \mathrm{~h}$ (Bagnyukova et al., 2007b). This increase in CAT activity generated by thermal stress can cause an enhancement of antioxidant potential including primary and associated antioxidant enzyme activities (Lushchak \& Bagnyukova, 2006; Vinagre et al., 2012).

This situation also occurs in animals with higher swimming activity also showed higher CAT activity values in the liver of rays and sharks compared to rested specimens, corresponding to the higher levels of oxygen consumption (Wilhelm Filho \& Boveris, 1993). According to our and other studies (Wilhelm Filho \& Boveris, 1993;
Lushchak \& Bagnyukova, 2006; Wilhelm Filho et al., 2001; Martínez-Álvarez et al., 2005), the optimum level of water temperature is dependent for each species, age and life stage; moreover the temperatures outside the optimal range may induce the oxidative stress. These physiological variations were observed in CAT activity which occur due to hydrogen peroxide concentrations increase in tissues in attempt to reach homeostasis by degradation of this $\mathrm{H}_{2} \mathrm{O}_{2}$ in oxygen and water. Induction of this enzyme induces protection systems after exposure to ROS being an important adaptive response to non-lethal effects of $\mathrm{H}_{2} \mathrm{O}_{2}$ (Moslen, 1992; Tort et al., 2005).

Here, the lower and higher temperature (17.1 and 28.8 ${ }^{\circ} \mathrm{C}$ ) demonstrated increased GST activity in the gill and liver of juveniles in first $3 \mathrm{~h}$ in relation to the control. Higher GST activity may be explained by their anti-oxidant action which may promote a protective mechanism in different tissues (Zhang et al., 2003; Lushchak \& Bagnyukova, 2006). In other work can also be observed increase in GST activity in liver and white muscle of Nile tilapia juveniles exposed to 5 and $10 \mathrm{mg} \mathrm{L}^{-1}$ total ammonia concentrations. Differently of our study in goldfish the GST activity was not affected with heat shock in brain and muscle, however, in liver occurred an increase after $24 \mathrm{~h}$ (Lushchak \& Bagnyukova, 2006). The GST levels can be significantly increased by exposure to different environmental pollutants (chemicals or water quality parameters), suggesting that this increase is part of an adaptive response to stress and their action avoids damage to the biological systems.

These evidences allow us to conclude that $P$. orbignianus when submitted to cold and heat shocks present alterations in LPO levels and enzymatic activity in liver and gill, in response to ROS production by thermal shocks. This condition causes a more energy expenditure to attenuate ROS production (Souza et al., 2014) and, as a result, lower animal growth in fish culture (Wei-Na et al., 2006).

\section{Acknowledgments}

M. H. Okamoto is a postdoctoral supported by Fundação de Amparao à Pesquisa do Estado do Rio Grande do Sul (FAPERGS). L. A. Sampaio and L. O. Garcia are research fellow of the Conselho Nacional de Desenvolvimento Científico e tecnológico - CNPq (Process 308013/2009-3 and 150458/2010-0, respectively). This work was partially supported by FAPERGS (Process 9505355) and CNPq (Process 480397/2010-4 and 556426/2009-6).

\section{References}

Azambuja, C. R., J. Mattiazzi, A. P. K. Riffel, I. A. Finamor, L. O. Garcia, C. G. Heldwein, B. M. Heinzmann, B. Baldisserotto, M. A. Pavanato \& S. F. Llesuy. 2011. Effect of the essential oil of Lippia alba on oxidative stress parameters in silver catfish (Rhamdia quelen) subjected to transport. Aquaculture, 319: 156-161. 
Bagnyukova, T. V., O. I. Chahrak \& V. I. Lushchak. 2006. Coordinated response of goldfish antioxidant defenses to environmental stress. Aquatic Toxicology, 78: 325-331.

Bagnyukova, T. V., S. I. Danyliv, O. S. Zin'ko \& V. I. Lushchak. 2007a. Heat shock induces oxidative stress in rotan Perccottus glenii tissues. Journal of Thermal Biology, 32: 255-260.

Bagnyukova, T. V., O. V. Lushchak, K. B. Storey \& V. I. Lushchak. 2007 b. Oxidative stress and antioxidant defense responses by goldfish tissues to acute change of temperature from 3 to $23{ }^{\circ} \mathrm{C}$. Journal of Thermal Biology, 32: 227-234.

Baumgarten, M. G. Z., J. M. B. Rocha \& L. F. H. Niencheski. 1996. Manual de análises em oceanografia química. Rio Grande, Ed. da FURG, 132p.

Bendschneider, K. \& R. J. Robinson. 1952. A new spectrophotometric method for the determination of nitrite in sea water. University of Washington, Oceanographic Laboratories, 18p. + ap. (2p.). (Technical report, no. 8).

Bhat, S. \& P. V. Desai. 1998. Effect of thermal and salinity stress on Perna viridis heart (L.). Indian Journal of Experimental Biology, 36: 916-919.

Bianchini, A., W. Wasielesky, Jr. \& K. C. Miranda Filho. 1996. Toxicity of nitrogenous compounds to juveniles of flatfish Paralichthys orbignyanus. Bulletin of Environmental Contamination and Toxicology, 56: 453-459.

Boveris, A. \& B. Chance. 1973. The mitochondrial generation of hydrogen peroxide general properties and effect of hyperbaric oxygen. Biochemical Journal, 134: 707-716.

Buege, J. A. \& S. D. Aust. 1978. Microsomal lipid peroxidation. Methods in Enzymology, 52: 302-310.

Chow, C. K. 1991. Vitamin E and oxidative stress. Free Radical Biology and Medicine, 11: 215-232.

Figueiredo, J. L. \& N. A. Menezes. 2000. Manual de peixes marinhos do sudeste do Brasil. São Paulo, Museu de Zoologia da Universidade de São Paulo, v.6, pte. 5: Teleostei. (116p.).

Garcia, A. M., J. P. Viera \& K. O. Winemiller. 2003. Effects of 1997-1998 El Niño on the dynamics of the shallow-water fish assemblage of the Patos Lagoon Estuary (Brazil). Estuarine, Coastal and Shelf Science, 57: 489-500.

Habig, W. H., M. J. Pabst \& W. B. Jakoby. 1974. Glutathione S-transferases: the first enzymatic step in mercapturic acid formation. The Journal of Biological Chemistry, 249: 7130-7139.

Halliwell, B. 1992. Reactive oxygen species and the central nervous system. Journal of Neurochemistry, 59: 1609-1623.

Halliwell, B. \& J. M. C. Gutteridge. 1999. Free radicals in biology and medicine. 3rd ed. Clarendon Press; New York, Oxford University Press, 936p.

Hermes-Lima, M. 2004. Oxygen in biology and biochemistry: role of free radicals. Pp. 319-368. In: Storey, K. B. (Ed.). Functional metabolism: regulation and adaptation. Hoboken, NJ, J. Wiley \& Sons.

Lowry, O. H., N. J. Rosebrough, A. L. Farr \& R. J. Randall. 1951. Protein measurement with the folin phenol reagent. The Journal of Biological Chemistry, 193: 265-275.

Lushchak, V. I. \& T. V. Bagnyukova. 2006. Temperature increase results in oxidative stress in goldfish tissues. 2. Antioxidant and associated enzymes. Comparative Biochemistry and Physiology, Part C 143: 36-41.

Malek, R. L., H. Sajadi, J. Abraham, M. A. Grundy \& G. S. Gerhard. 2004. The effects of temperature reduction on gene expression and oxidative stress in skeletal muscle from adult zebrafish. Comparative Biochemistry and Physiology, Part C 138: 363-373.

Martínez-Álvarez, R. M., A. E. Morales \& A. Sanz. 2005. Antioxidant defenses in fish: Biotic and abiotic factors. Reviews in Fish Biology and Fisheries, 15: 75-88.
Matés, J. M., C. Pérez-Gómez \& I. Núñez de Castro. 1999. Antioxidant enzymes and human diseases. Clinical Biochemistry, 32: 595-603.

Moslen, M. T. 1992. Protection against free radical mediated tissue injury. Pp. 203-215. In: Moslen, M. T. \& C. V. Smith (Eds.). Free radical mechanisms of tissue injury. Boca Raton, CRC Press.

Sampaio, L. A. \& A. Bianchini. 2002. Salinity effects on osmoregulation and growth of the euryhaline flounder Paralichthys orbignyanus. Journal of Experimental Marine Biology and Ecology, 269: 187-196.

Sampaio, L. A., L. S. Freitas, M. H. Okamoto, L. R. Louzada, R. V. Rodrigues \& R. B. Robaldo. 2007. Effects of salinity on Brazilian flounder Paralichthys orbignyanus from fertilization to juvenile settlement. Aquaculture, 262: 340-346.

Souza, D. M., A. C. Martins, L. Jensen, W. Wasielesky, Jr., J. M., Monserrat \& L. O. Garcia. 2014. Effect of temperature on antioxidant enzymatic activity in the Pacific white shrimp Litopenaeus vannamei in a BFT (Biofloc technology) system. Marine and Freshwater Behaviour and Physiology, 47: 1-10.

Storey, K. B. 1996. Oxidative stress: animal adaptations in nature. Brazilian Journal of Medical and Biological Research, 29: 17151733.

Tort, L. 2011. Stress and immune modulation in fish. Developmental and Comparative and Immunology, 35: 1366-1375.

Tort, M. J., D. Hurley, C. Fernandez-Cobas, G. A. Wooster \& P. R. Bowser. 2005. Effects of hydrogen peroxide treatments on catalase and glutathione activity in Walleye Sander vitreus. Journal of the World Aquaculture Society, 36: 577-586.

Unesco. Intergovernmental Oceanographic Commission. 1983. Chemical methods for use in marine environmental monitoring. Paris, France, 53p. (Manuals and guides, 12).

Vinagre, C., D. Madeira, L. Narciso, H. N. Cabral \& M. Diniz. 2012. Effect of temperature on oxidative stress in fish: Lipid peroxidation and catalase activity in the muscle of juvenile seabass, Dicentrarchus labrax. Ecological Indicators, 23: 274-279.

Wasielesky, W., Jr., A. Bianchini \& K. Miranda Filho. 1998. Tolerancia a la temperatura de juveniles de lenguado Paralichthys orbignyanus. Frente Marítimo, 17: 43-48.

Wasielesky, W., Jr., A. Bianchini, M. H. S. Santos \& L. H. Poersch. 1997. Tolerance of juveniles flatfish Paralichthys orbignyanus to acid stress. Journal of the World Aquaculture Society, 28: 202-204.

Watters, K. W., Jr. \& L. S. Smith. 1973. Respiratory dynamics of the starry flounder Platichthys stellatus in response to low oxygen and high temperature. Marine Biology, 19: 133-148.

Wei-Na, Wang, W. An-Li, L. Yuan, X. Jun, L. Zhen-Bo \& S. Ru-Yong. 2006. Effects of temperature on growth, adenosine phosphates, ATPase and cellular defense response of juvenile shrimp Macrobrachium nipponense. Aquaculture, 256: 624-630.

Wilhelm Filho, D. \& A. Boveris. 1993. Antioxidant defences in marine fish - II. Elasmobranchs. Comparative Biochemistry and Physiology, Part C 106: 415-418.

Wilhelm Filho, D., M. A. Torres, T. B. Tribess, R. C. Pedrosa \& C. H. L. Soares. 2001. Influence of season and pollution on the antioxidant defenses of the cichlid fish acará (Geophagus brasiliensis). Brazilian Journal of Medical and Biological Research, 34: 719-726.

Zhang, J. F., H. Shen, T. L. Xu, X. R. Wang, W. M. Li \& Y. F. Gu. 2003. Effects of long-term exposure of low-level diesel oil on the antioxidant defense system of fish. Bulletin of Environmental Contamination and Toxicology, 71: 234-239.

Submitted October 01, 2014

Accepted May 07, 2015 by Bernardo Baldisserotto Published September 25, 2015 